Metallophysics and Advanced Technologies

металофіз. новітні технол.

Metallofiz. Noveishie Tekhnol.

2020 , vol. 42 , No. 10 , pp. $1441-1454$

https://doi.org/10.15407/mfint.42.10.1441

Reprints available directly from the publisher

\section{PHYSICAL AND TECHNICAL BASIS OF EXPERIMENT AND DIAGNOSTICS}

PACS numbers: 07.05.Mh, 07.60.-j, 07.81.+a, 61.82.Bg, 79.60.-i, 81.70.Jb

\title{
Artificial Neural Network as a Part of Intelligent Precise Goniometric System for Analysis of Spectral Distribution Intensity and Definition of Chemical Composition of Metal-Containing Substances
}

\author{
I. Cherepanska, Yu. Koval ${ }^{* * * *}$, O. Bezvesilna**, \\ A. Sazonov**, and S. Kedrovskyi*,** \\ Zhytomyr National Agroecological University, \\ 7 Staryi Bulvar Str., \\ UA-10008 Zhytomyr, Ukraine \\ "G.V. Kurdyumov Institute for Metal Physics, N.A.S. of Ukraine, \\ 36 Academician Vernadsky Blvd., \\ UA-03142 Kyiv, Ukraine \\ *National Technical University of Ukraine \\ 'Igor Sikorsky Kyiv Polytechnic Institute', \\ 37 Peremohy Ave., \\ UA-03056 Kyiv, Ukraine
}

An artificial neural network (ANN) is proposed, which allows to make express-analysis of the chemical composition of production objects metalcontaining materials in automatic mode with high accuracy and real-time performance. The proposed ANN for automatic recognition of chemicals (ANN ARoC) is an alternative to traditional high-cost and time-consuming physical and chemical methods and labelling analysis, which are significantly complicate and slow down technological processes, as well as environmentally hazardous to human health and environment. The mean square error of proposed ANN ARoC does not exceed 5\%, the time of determining the chemical composition of production objects metal-containing materials is not more than $2.5 \mathrm{~s}$. ANN ARoC is built on the principle of a multilayer perceptron

Corresponding author: Iryna Yuriyivna Cherepanska

E-mail: cherepanskairina@gmail.com

Citation: I. Cherepanska, Yu. Koval, O. Bezvesilna, A. Sazonov, and S. Kedrovskyi, Artificial Neural Network as a Part of Intelligent Precise Goniometric System for Analysis of Spectral Distribution Intensity and Definition of Chemical Composition of Metal-Containing Substances, Metallofiz. Noveishie Tekhnol., 42, No. 10: 1441-1454 (2020), DOI: 10.15407/mfint.42.10.1441. 
with a tunable structure of neurons and practically implemented in the form of an appropriate software product. The latter ensures its versatility in terms of the possibility of retraining and readjustment when new tasks arise in accordance with the rapidly changing conditions of modern dynamic production.

Key words: artificial neural network, photosensitive CMOS-matrix, laser, chemical composition, spectral distribution, saturation current, light wavelength, sensitivity of photocells.

Запропоновано штучну нейронну мережу (ШНM), яка дозволяє здійснювати експрес-аналіз хімічного складу металовмісних матеріалів об'єктів виробництва в автоматичному режимі з високою точністю та швидкодією у реальному часі. Пропонована ШНМ автоматичного розпізнавання хемічних речовин (ШНМ AРXР) є альтернативою традиційним високовартісним і трудомістким фізико-хімічним методам та маркувальному аналізу, які значно ускладнюють та сповільнюють технологічні процеси, а також $є$ екологічно небезпечними для здоров'я людей та навколишнього середовища. Середня квадратична похибка роботи запропонованої ШНМ АРХР не перевищує $5 \%$, час визначення хімічного складу металовмісних матеріалів об'єктів виробництва не перевищує 2,5 с. ШНМ АРХР побудовано за принципом багатошарового перцептрону 3 налагоджуваною структурою нейронів та практично реалізовано у вигляді відповідного програмного продукту. Останнє забезпечує її універсальність щодо можливості перенавчання та переналагодження у разі виникнення нових задач відповідно до швидко змінюваних умов сучасного динамічного виробництва.

Ключові слова: штучна нейронна мережа, фоточутлива CMOS-матриця, лазер, хімічний склад, спектральний розподіл, струм насичення, довжина світлової хвилі, чутливість фотоелементів.

(Received June 5, 2020)

\section{INTRODUCTION}

Real-time high accuracy automated determination of the chemical composition of production objects (PO) metal-containing materials is an extremely important and specific task of modern metallurgical, machine-building, processing, etc. productions. The relevance of this task is caused by ever-increasing requirements of global industrial market and international product quality standards. Its successful solving promotes to the stability of technological processes, the required product quality and competitiveness of enterprises in general.

Determination of the chemical composition of PO metal-containing materials in modern flexible and continuous productions usually is performed by rapid analysis using special measuring instruments, as well as appropriate physical and chemical methods in conjunction with marking analysis. The last despite the relatively high accuracy of determining the chemical components in PO materials, according to sci- 
entists and manufacturers [1,2], involve a number of high-cost, timeconsuming and complex operations that significantly complicate and slow down technological processes, and are environmentally hazardous to human health and the environment. In view of the above there is no doubt in necessity of automation the express analysis of the chemical composition determination of PO metal-containing materials, aimed to improve performance with high accuracy. This can be achieved through the synergistic integration of the latest advances in science and technology in the field of information and computer technology, electronics and laser spectroscopy. In particular, it is by using the latest neural network technologies with the development of an appropriate artificial neural network (ANN). The advantages of using neural network technologies to solve this problem are undeniable, given the experience of development and application of ANN to handle information in a highly dynamic environment, high accuracy and speed of their work in real time.

Analysis of known studies and publications [3-6] showed that to determine the intensity of the spectral distribution of chemicals in metalcontaining materials X-ray and laser spectrometers are used, the operation of which involves short-term irradiation of the studied PO with a concentrated and powerful energy pulse. As a result, a radiation spectrum of different intensity is formed due to different ability of energy absorbing by atoms of different substances contained in metals. The presence of the corresponding chemical compounds in metals is determined by the results of measuring the scattering angle of the emitted light. Today, the list of modern tools for determining the chemical composition of metal-containing substances is quite significant. Some of widely used devices are the optical emission spectrometer ARL 4460 (Thermo Fisher Scientific, USA) [3], the emission spectrometer 'Iskroline 100' (the company 'Iskroline', Russia) [4], the atomic emission spectrometer 'ISKROLINE 300' (the company 'Iskroline', Russia) [5], spectrophotometer ULAB 102 (Ulab, China) [6]. Analysis of the principles of construction and operation of these tools allows us to state that they all have different measurement ranges, low accuracy (for example, the relative random error of the emission spectrometer 'Iskroline 100' and atomic emission spectrometer 'ISKROLINE 300' is about 0.5 to $40 \%[4,5]$ ) and insufficient speed (for example, the duration of chemical elements determination by optical emission spectrometer ARL 4460 [3] is up to 1 min). Known tools are based on the use of various complex mathematical models, methods, and algorithms for information processing, such as multidimensional analysis by least squares [7], calculations of multidimensional regression in orthogonal Chebyshev polynomials, which are transformed into algebraic polynomials [8], etc. It is not possible to use such complex methods and algorithms in real time. 
In view of the above, it can be argued that today, despite the obvious significant scientific and practical achievements in this field, the task of automated determination of the chemical composition of metalcontaining materials with high real-time performance and high accuracy is not yet fully solved.

An alternative to the above known methods may be a known intelligent precise goniometric system (IPGS), which is used for precision goniometric measurements, as well as to determine the chemical composition of metal-containing substances in PO in real time [9]. IPGS is based on the known goniometric system with a ring laser GS1L [10] and is organized as a functional set of different technical methods with other properties. The main new elements that have been isolated and additionally introduced into the system are the photosensitive matrix on the complementary metal-oxide-semiconductor structures-CMOSmatrix and ANN [9]. The operation of the CMOS-matrix and ANN is based on the physical phenomena of laser spectroscopy, the principles of semiconductor photosensitive elements and neural network technologies. Synergetic integration of CMOS-matrix and ANN in IPGS allows to apply the latest methods of automated processing of measuring information in determining the chemical composition of metalcontaining materials with higher real-time performance (up to $2.5 \mathrm{~s}$ ) and accuracy (at least $95 \%$ ).

It is known that ANN are successfully used to solve various problems of data processing and analysis in conditions of incompleteness, contradictory and high dynamics of input information based on the methods of parallel processing. So there are a number of works in which ANN are used in the algorithm for estimating the bending angles of the knees [11], in the method of predicting the bending angle of the finger joint [12], in the method of estimating the angle and speed of the generator rotor, in particular to assess the stability and control of transients in real-time mode [13], in the method of determining the component errors of measuring angles on the principle of their decomposition [14]. In publications [11-14] it is proved that the use of ANN allows increasing the speed, accuracy and productivity of work performed.

Purpose. Develop an artificial neural network for automatic recognition of chemicals (ANN ARoC), as part of the known IPGS for express analysis of the spectral distribution intensities of the chemical substances for definition of their content in PO metal-containing materials with higher speed and accuracy in real time.

\section{DESCRIPTION OF THE PROPOSED ARTIFICIAL NEURAL NETWORK OF AUTOMATIC RECOGNITION OF CHEMICAL SUBSTANCES}

The proposed ANN ARoC is a component of IPGS and performs the op- 
eration of automatic recognition of chemical elements in metalcontaining materials of different PO by their spectral distribution, which is formed on the surface of the CMOS-matrix in real time. Developed ANN on the type of implementation of neuroalgorithms, the nature of the implementation of nonlinear transformations and the possibility of construction, is implemented on one of the known models (multilayer perceptron) with a customizable structure of neurons.

Figure 1 presents a schematic model of the developed ANN ARoC. The basic unit of information processing in ANN, including ANN ARoC is a neuron, which produces the output OUT, forming the sum of the products of the weights $w$ of the inputs $x$. The mathematical model of the neuron is represented by a well-known expression given in the paper [9].

ANN ARoC performs the operation of recognizing chemical elements that may be contained in metal-containing PO materials by their spectral distribution, which is formed on the surface of the CMOSmatrix and induces saturation currents $i_{i}\left(\lambda_{i}\right)$ in its sensitive elements (pixels). The input signals of ANN ARoC meaningfully reflect the in-

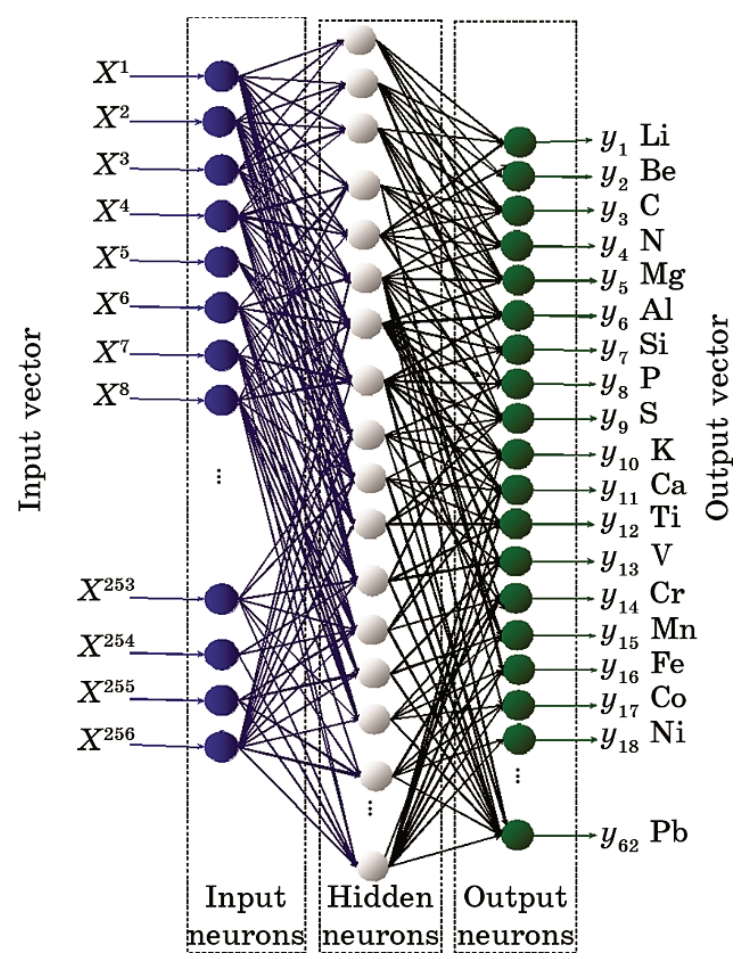

Fig. 1. Schematic model of the developed ANN ARoC: input neurons 256, hidden neurons 275 , output neurons 62 . 
tensity of the reflected light radiation, which depends on the chemical composition of metals. Thus, a set of saturation currents of the photocells of the CMOS-matrix is fed to the input of the ANN ARoC when they are irradiated with light with wavelengths $\lambda_{i}:\left\{i_{i}\left(\lambda_{i}\right) \mid i \in\{\mathrm{C}, \mathrm{P}, \mathrm{S}\right.$, $\mathrm{Mn}, \mathrm{Si}, \mathrm{Cr}, \mathrm{Ni}, \mathrm{Cu}, \mathrm{Nb}, \mathrm{N}, \mathrm{Al}, \mathrm{Ti}, \mathrm{V}, \mathrm{Mo}, \mathrm{W}$, Co, B, Fe, ...\}, where C, P, $\mathrm{S}, \mathrm{Mn}, \mathrm{Si}, \mathrm{Cr}, \mathrm{Ni}, \mathrm{Cu}, \mathrm{Nb}, \mathrm{N}, \mathrm{Al}, \mathrm{Ti}, \mathrm{V}, \mathrm{Mo}, \mathrm{W}, \mathrm{Co}, \mathrm{B}, \mathrm{Fe}-$ symbols of some elements that may be contained in the PO materials. The set of saturation currents, in accordance with the requirements of the ANN technology, forms an input vector $X$ supplied to the inputs of the ANN. The size of the input vector is defined as follows:

$$
\begin{gathered}
X=\left\{x_{s} \mid s=\overline{1, S}\right\}, \\
S=c r,
\end{gathered}
$$

where $c$ is number of columns of the CMOS-matrix, $r$ is number of rows of the CMOS matrix.

For example, when using a CMOS-matrix OV16880 or OV20880 manufactured by OmniVision (USA), $S$ is 307500 pixels.

Pre-normalized values of spectral distribution intensities, which have a digital form and contain 256 components, are fed to the input of the proposed ANN, so the number of input neurons is 256 .

As a result of the work of the proposed ANN ARoC at its outputs a digital signal is formed in the form of a vector $Y$, which reflects the chemical composition of the material of the studied PO:

$$
Y=\left\{y_{m} \mid m=\overline{1, M}\right\},
$$

where $y_{m}$ is the output signal of the proposed ANN ARoC, which corresponds to the presence of the $m$-th chemical element in the PO metalcontaining material; $M$ is the number of chemical elements that can be determined. The maximum value of $y_{m}$ at the $m$-th corresponding output of ANN ARoC corresponds to the presence in the composition of $\mathrm{PO}$ of a certain chemical element.

The dimension of the source layer of the proposed ANN ARoC is 62 neurons, according to the list of chemical elements that may be contained in metal-containing substances. The dimension of the hidden layer is determined empirically by the results of ANN training and is 275 neurons.

The decision on the presence of a chemical element in the PO material is made by the so-called interpreter of the answer 'the winner takes all', in which the number of output signals corresponds to the number of response options, and the response number corresponds to the number of neuron that issued the maximum signal. When determining the chemical composition of PO materials at the corresponding outputs of the ANN ARoC, a digital code is formed, and the maximum values of 
the signals correspond to the presence of the corresponding chemical elements.

In general, the task of identification of chemicals in the composition of metal-containing materials of various PO proposed ANN ARoC can be represented as follows. Based on the set of digital signals (including currents $i(\lambda)$ of photocells saturation) from the CMOS-matrix, which receives the proposed ANN ARoC during the short-term irradiation of the PO surface with a concentrated and powerful energy pulse of the laser emitter IPGS (Fig. 2), it is automatically determined what chemical elements are contained in the PO metal-containing materials. To do this, the drive 1 of IPGS rotation (see Fig. 2) is mechanically connected to the objective table 2 , which is mounted on the rotating device 3 . There are rigidly fixed a ring laser 4 and an autocollimator 5 with a laser emitter 6 , CMOS-matrix 7 for recording radiation in the infrared and ultraviolet range, which are connected to the power supply 8 .

The investigated $\mathrm{PO}$ is mounted on a rotating table 2 . PO is exposed to a short-term irradiation of a concentrated and powerful energy pulse from the laser emitter 6 . The generated light flux is projected from the optical system 5 on the CMOS-matrix 7 , which converts it into a corresponding electric signal. The electric signal from the CMOSmatrix 7 through the control unit 8 is transmitted to the ANN ARoC, which determines the chemical composition of the investigated PO material. Different chemical elements that can be contained in the PO,

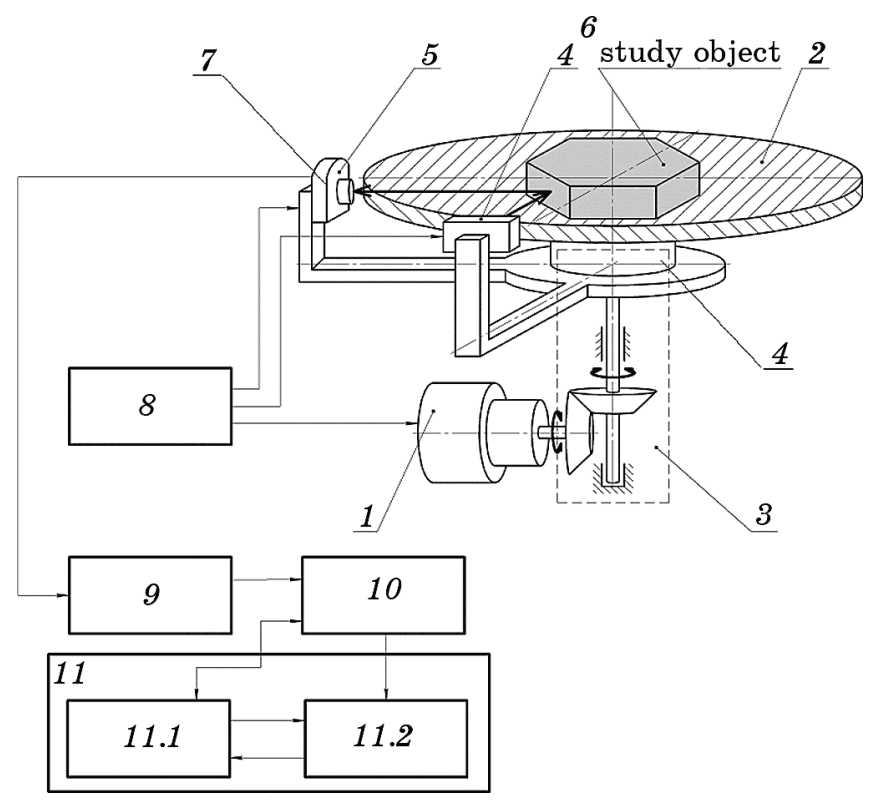

Fig. 2. IPGS flowchart. 
absorb the energy pulse from the laser 6 with different intensities, and form different light fluxes that are reflected at different angles and, accordingly, projected at different positions on the CMOS-matrix 7 . The absorbing ability of metals does not depend on the frequency of incident laser radiation and is determined only by the electrical properties of materials, which, in turn, depend on the chemical composition. As a result, a spectrum of radiation of different intensity is formed.

The presence of the corresponding compounds in PO metalcontaining materials is determined by measuring the scattering angle of the emitted light. In particular, the scattered emitted light when exposed to photosensitive elements (pixels) of the CMOS-matrix at appropriate angles synthesize saturation currents $i(\lambda)$ in photosensitive elements of the CMOS-matrix, the values of which are determined by the chemical composition of the investigated material (Fig. 3). The set of saturation currents $i(\lambda)$ in the photosensitive elements of the CMOSmatrix forms a corresponding set of digital signals $\alpha_{i n}^{D} \in\left\{U_{3 M} f[i(\lambda)]\right\}$, that is transmitted to the input of the proposed ANN ARoC. The input

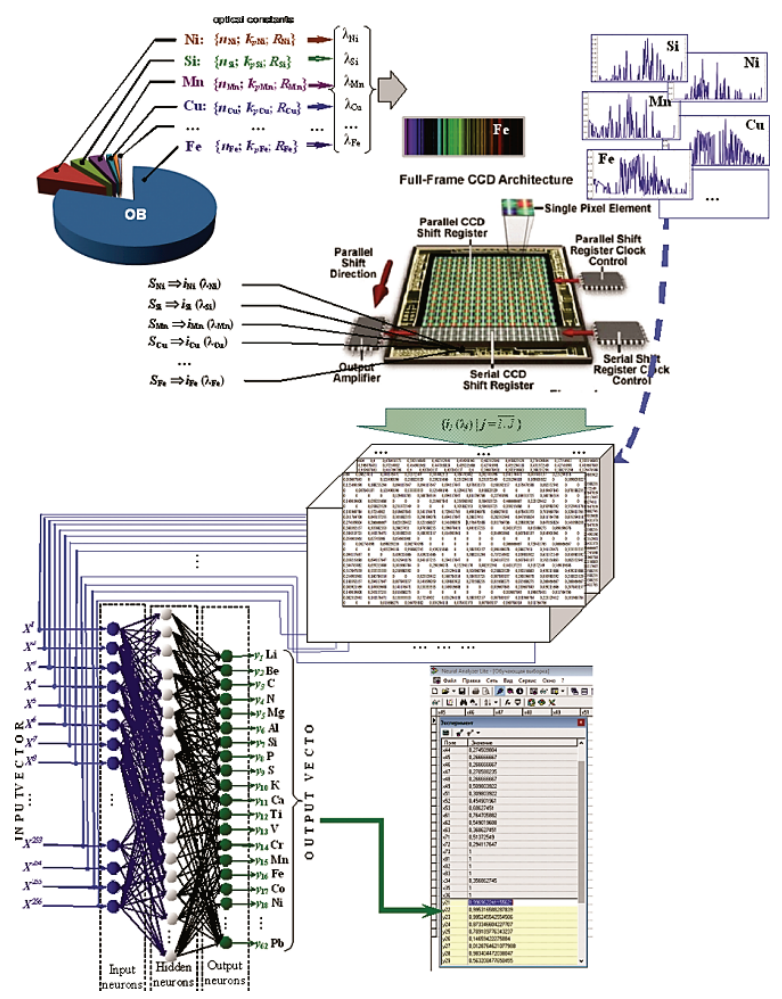

Fig. 3. Schematic representation of the functional interaction of ANN ARoC with CMOS-matrix in IPGS during definition of chemical elements in PO metal-containing materials. 
signals of SHNM ARHR meaningfully reflect the intensity of the reflected light radiation, which depends on the chemical composition of the PO materials. The set of saturation currents, in accordance with the requirements of the ANN technology, forms the input vector $X$, which is fed to the inputs of the ANN ARoC. The dimension of the input vector $X$ and the number of neurons at the input of the proposed ANN ARoC, which is designed to receive input information from the CMOS-matrix, is determined by the resolution of the last one.

In addition, the system contains a computer 11, in which in real time in the appropriate software module (block 11.1 in Fig. 2) the analysis and processing of results from ANN ARoC and decision making are performed, as well as automated measurement data processing with the presentation of results in a user-friendly form through the user interface 11.2.

\section{METHODS OF FORMING THE TRAINING SET DATABASE AND TRAINING ANN ARoC}

For training ANN ARoC it is performed an appropriate training set (TS) or training database (DB) with a set of training examples $\langle X, Y\rangle$, where $X=\left(X_{1}, X_{2}, \ldots, X_{S}\right)$-vector of input data (signals) ANN ARoC; $Y=\left(Y_{1}, Y_{2}, \ldots, Y_{N}\right)$-vector of output data (signals) ANN ARoC. The dimension of TS is 150 training examples and 120 test cases. The TS fragment is given in Table 1.

The examples of TS given in Table 1 are normalized and presented in the form of a digital code the voltage values of the outputs of the CMOS-matrix photosensitive elements depending on the intensity of the spectral distribution of the corresponding chemical elements (for example, Aluminium, Calcium, Bromine and Barium), which may be contained in PO metal-containing materials. The training database was synthesized by hardware measurement using an intelligent precision goniometric system and by simulation on a PC, due to the impossibility of practical obtaining the whole set of results of experimental instrumental measurement of saturation currents $i_{i}\left(\lambda_{i}\right)$ of all possible chemical elements of PO metal-containing materials.

The training of the proposed ANN ARoC is carried out according to the method of 'teaching with a teacher' and the well-known algorithm bask propagation.

The construction and training of the proposed ANN ARoC is carried out using the neuroimulator Neural Analyser of analytical package Deductor Professional (Lite-version) and Excel spreadsheet. By sequential changing the number of neurons $L$ in the hidden layer in the range [1, 280], calculated by expressions (3) and (4), the following ANN ARoC architecture is determined: multilayer network of direct propagation with dimension of input layer 256 neurons, hidden -275 
TABLE 1. The TS fragment for training ANN ARoC.

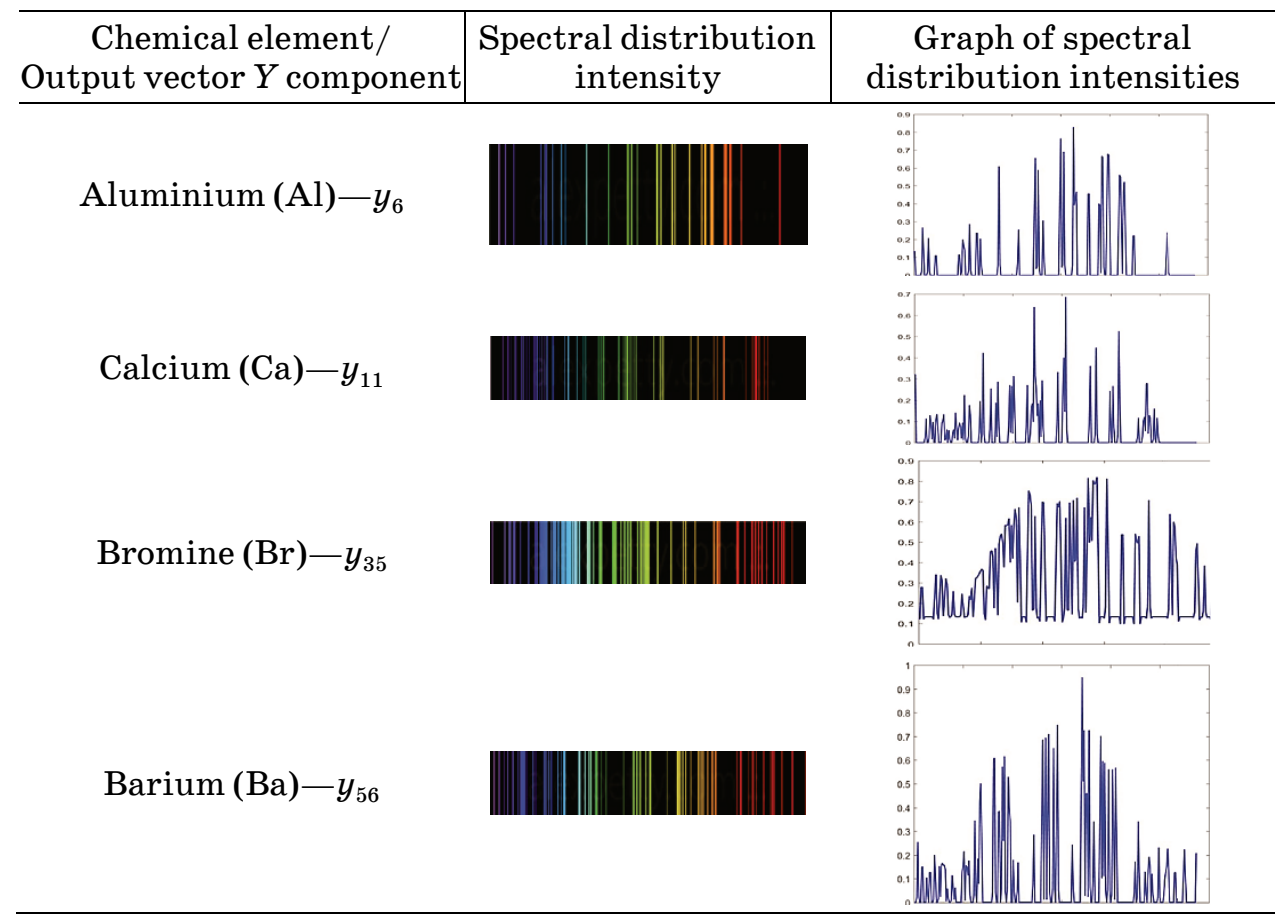

neurons, output-62 neurons, activation function of neuronssigmoid (or Fermi function):

$$
L=\frac{L_{w}}{n+m},
$$

where $L$ is the number of neurons in the hidden layer, $L_{w}$ is the number of synaptic weights of neurons. Here $n$ is the dimension of the input layer of the ANN, $m$ is the dimension of the output layer of the ANN:

$$
\frac{m N}{1+\log _{2} N} \leq L_{w} \leq m\left(\frac{N}{m}+1\right)(n+m+1)+m,
$$

where $N$ is the number of examples in the training set database.

The value of the error $E$, which should not exceed 0.05 or $5 \%$, is accepted as an evaluative training functional of the ANN ARoC. The results of training are presented in Fig. 4, illustrating the value of the mean-square error $E$ of the ANN ARoC operation in determining the presence of various chemical elements. Figure 4 shows that during the ANN ARoC work the value of the error in determining the chemical elements do not exceed $5 \%$, what indicates excellent training results. 


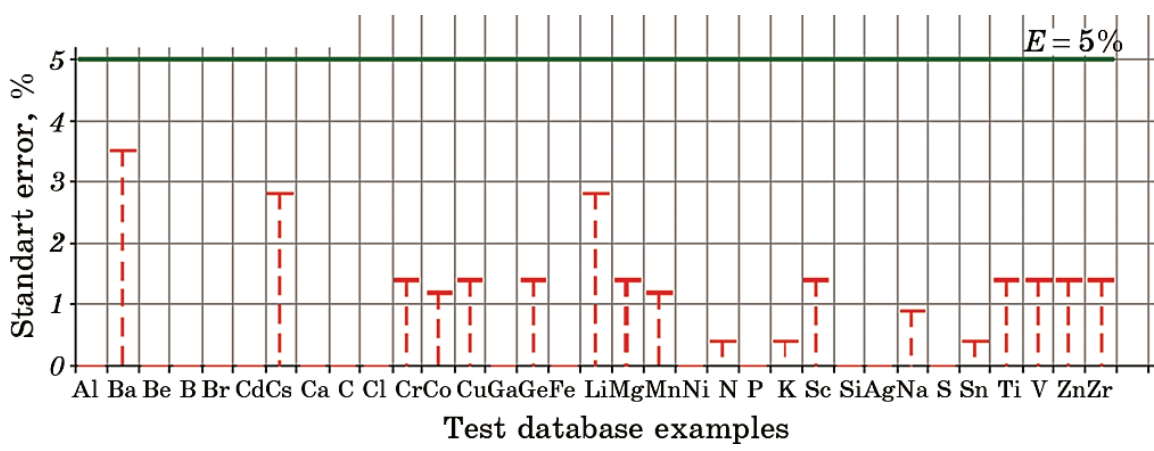

Fig. 4. Graphical representation of the mean-square error $E$ value during the operation of the developed ANN ARoC under the condition $E \leq 5 \%$.

\section{PRACTICAL IMPLEMENTATION AND RESULTS OF THE ANN AROC WORK COMPUTER SIMULATION}

ANN ARoC is practically implemented by using the neuroemulator Neural Analyzer of the analytical package Deductor Professional (Liteversion) [16], and is integrated as a specialized software application into the operating system of a personal computer, which is equipped into IPGS. The high speed of determining the chemical composition of the PO material in real time is ensured by the fact that in the ANN ARoC a method of parallel data processing is implemented, according to which the information supplied to the ANN ARoC is processed all simultaneously and not sequentially. The total time of determination of chemicals in the PO materials does not exceed $2.5 \mathrm{~s}$.

Computer simulation of the developed ANN ARoC is performed. ANN ARoC demonstrated high speed of performance (time of determination of chemical elements did not exceed $2.5 \mathrm{~s}$, what corresponds to the real time mode) and high accuracy of determination of chemical elements (the rate of the evaluating functional corresponds to the accepted value, $E \leq 5 \%$ (Fig. 4 )).

Interpretation of the ANN ARoC work results. Analysing the above, it can be said about the excellent work of ANN ARoC, as indicated by the following:

1. Positive results of ANN ARoC work are obtained for the entire test set of the measured $\mathrm{PO}$ materials spectral distribution value;

2 . The probability of the correct answer of ANN ARoC is at least $95 \%$

3 . The mean square error of ANN ARoC does not exceed $5 \%$;

4. The operating time of ANN ARoC does not exceed $2.5 \mathrm{~s}$, what corresponds to the real-time mode and indicates on the high speed of the 
TABLE 2. Comparative characteristics of the proposed ANN ARoC with known methods.

\begin{tabular}{|c|c|c|c|c|c|c|}
\hline Name & $\begin{array}{c}\text { Accu } \\
\text { cu- } \\
\text { racy }\end{array}$ & $\begin{array}{l}\text { Perfor- } \\
\text { mance }\end{array}$ & $\begin{array}{c}\text { Work } \\
\text { in real } \\
\text { time } \\
\text { mode }\end{array}$ & $\begin{array}{l}\text { Auto- } \\
\text { mated } \\
\text { data } \\
\text { pro- } \\
\text { cessing }\end{array}$ & $\begin{array}{c}\text { Versatility (possi- } \\
\text { bility of readjust- } \\
\text { ment and/or in- } \\
\text { crease the list of } \\
\text { chemical elements) }\end{array}$ & $\begin{array}{l}\text { Compatibility } \\
\text { of specialized } \\
\text { software and } \\
\text { OS Windows }\end{array}$ \\
\hline ANN ARoC & $95 \%$ & Up to $2.5 \mathrm{~s}$ & + & + & + & + \\
\hline $\begin{array}{c}\text { Optical emission } \\
\text { spectrometer ARL } \\
4460[3]\end{array}$ & $90 \%$ & $\begin{array}{l}\text { Up to } \\
1 \text { min }\end{array}$ & - & + & - & - \\
\hline $\begin{array}{l}\text { Emission spec- } \\
\text { trometer } \\
\text { 'Iskroline 100' [4] }\end{array}$ & $60 \%$ & $\begin{array}{l}\text { Up to } \\
2 \text { min }\end{array}$ & - & + & - & + \\
\hline $\begin{array}{l}\text { Atomic emission } \\
\text { spectrometer } \\
\text { 'ISKROLINE } \\
300 \text { ' [5] }\end{array}$ & $60 \%$ & $\begin{array}{l}\text { Up to } \\
2 \text { min }\end{array}$ & - & + & - & + \\
\hline $\begin{array}{l}\text { Spectrophotome- } \\
\text { ter ULAB } 102 \text { [6] }\end{array}$ & $85 \%$ & $\begin{array}{l}\text { Up to } \\
1 \mathrm{~min}\end{array}$ & - & + & - & - \\
\hline
\end{tabular}

system performance;

5. Comparing the proposed ANN ARoC with other known methods (Table 2) indicates its absolute advantage.

It is worth noting that the training of all ANN, without exception, including the proposed ANN ARoC, is a time-consuming process. At the same time, the quality of training and the reliability of further work of ANN ARoC depend on the following factors-the quality and dimension of the training set, and the qualifications of employees. This is due to the fact that the preparation of the training set requires from employees special knowledge and skills in the field of neural network technologies, and also requires the availability of a priori information about the conditions of experiments.

\section{CONCLUSIONS}

1. For the first time, an artificial neural network ANN ARoC is developed and studied, what allows automatic recognition of chemicals in metal-containing materials with high accuracy (at least 95\%) and speed (up to $2.5 \mathrm{~s}$, what corresponds to the real-time mode).

2. High performance of ANN ARoC is provided by simultaneous processing of multiple digital data by methods of parallel information processing. At the same time, the time spent on information pro- 
cessing is significantly reduced compared to the known results of scientific research and does not exceed $2.5 \mathrm{~s}$. Thus, real-time operation is provided.

3. High accuracy of ANN ARoC (the accuracy is at least 95\%, and the mean square error does not exceed $5 \%$ ) is achieved due to: determined experimentally sufficient dimension of the hidden layer, which has 275 neurons; training by the method of 'teaching with a teacher' and the algorithm bask propagation; high resolution sensitive elements that receive spectral radiation in the measuring system, in particular CMOS-matrix (it is proposed to use a matrix with a pixel dimension $1.0 \times 1.0 \mu \mathrm{m}$, for example, OV16880 or OV20880 of OmniVision production (USA)).

4. The developed ANN ARoC is a universal instrument of automation of process of the express analysis of chemical elements in materials of metal-containing PO due to the adjusted structure of neurons and practical program implementation. The above allows to change the structure of the proposed ANN ARoC and to carry out its retraining to solve new problems, as well as readjustment without additional capital investment in accordance with rapidly changing production conditions.

Thus, it can be argued that the developed ANN ARoC is the latest development, which is an alternative to traditional high-cost and timeconsuming physical and chemical methods and labelling analysis, which are significantly complicate and slow down technological processes, as well as environmentally hazardous to human health and environment. The implementation of the proposed ANN ARoC is appropriate and promising.

\section{REFERENCES}

1. D. Hryhorev, Ekspress-Analiz ili Khimicheskiy Analiz, Chto Luchshe? (in Russian), https://www.metalika.ua

2. A. I. Trotsan, Ya. P. Karlikova, O. V. Nosochenko, I. L. Brodetskiy, and B. F. Belov, Visnyk Pryazovskoho Derzhavnoho Tekhnichnoho Universytety. Seriya: Tekhnichni Nauky, No. 18: 71 (2008) (in Russian).

3. Optiko-Emissionnyy Spektrometr ARL 4460, https://thermotechno.ru/ catalog $/ 143 / 396$

4. Atomnye Optiko-Emissionnye Spektrometry, www.iskroline.ru/spectrometers

5. Direct Industry: Onlayn Vystavka Promyshlennoy Produktsii. Programmnoe Obespechenie dlya Spectrometrov, http://www.directindustry.com.ru/proizvoditel-promyshlennyj/ programmnoe-obespecenie-spektrometrov-109161.html

6. Spektrofotometr ULAB 102 (325-1000 $\mathrm{nm}$, Programmable), https://prom.ua/p99301350-spektrofotometr-ulab-102.html

7. Direct Industry: Onlayn Vystavka Promyshlennoy Produktsii. Programmnoe Obespechenie dlya Spectrometrov, 
http://www.directindustry.com.ru/proizvoditelpromyshlennyj/programmnoe-obespecenie-spektrometrov-109161.html

8. Programmnoe Obespechenie CATO, http://www.sp-an.com/software.htm

9. I. Cherepanska, O. Bezvesilna, Yu. Koval, and A. Sazonov, Metallofiz. Noveishie Tekhnol., 41, No. 2: 263 (2019).

10. Goniometric System GS1L. KP SPS Arsenal. Portal 'Manufactures of Machines and Equipment', http://ukraina.oborudunion.ru/i_store/item_1000014315/ ugloizmeritelnaya-sistema-gs1l.html

11. C. L. Bennett, C. Odom, and M. Ben-Asher, $29^{\text {th }}$ Southern Biomedical Engineering Conference (3-5 May, 2013) (Miami: 2013).

12. N. A. Shrirao, N. P. Reddy, and D. R. Kosuri, BioMedical Engineering OnLine, 8: 2 (2009).

13. A. D. Angel, M. Glavic, and L. Wehenkel, Using Artificial Neural Networks to Estimate Rotor Angles and Speeds from Phasor Measurements.

14. Irina Cherepanska, Elena Bezvesilna, Artem Sazonov, Sergey Nechai, and Oleksandr Pidtychenko, Eastern-European J.Enterprise Technologies, 5, No. 9 (95): 43 (2018).

15. I. Cherepanska, A. Sazonov, and O. Bezvesilna, Visnyk Khmelnytskoho Natsionalnoho University, Seriya: Tekhnichni Nauky, 269, No. 1: 130 (2019) (in Ukrainian).

16. Analytic Package Deductor Professional (BaseGroupLabs: 2002), p. 184. 